\title{
CHEMICAL CHARACTERISTICS OF FISH POND BOTTOM SEDIMENT AS A FUNCTION OF ORGANIC MATTER CONTENT
}

SAMIR M. SAEED AND MOSTAFA A. EL-GAMMAL

Central Lab. for Aquaculture Research, ARC, Limnology dept.

(Manuscript received 24 March 2009)

\begin{abstract}
Some chemical properties of sediment and distribution of some metals (iron, zinc, copper, manganese, cadmium and lead) were studied in the upper $10 \mathrm{~cm}$ of 12 fish ponds from four farms situated in different regions in Egypt namely, Abbassa, Sahl El-Tina, Wadi El-Raiyan and Belkas (Sharkia, Port Saeed, Fayoum and Dakahlia Governorate, respectively) to evaluate their stability for fish culture. The study showed that the sediment $\mathrm{pH}$ lied in the alkaline side and negatively correlated with organic matter contents. The sediment concentrations of nutrients, major ions and metals showed positive correlation $(P<0.05)$ with organic matter. Organic matter in sediments of Abbassa \& Sahl El-Tina ponds increased compared to the other ponds. The different studied variables (nutrients, major ions and metals) were greater $(P<0.05)$ in ponds of Abbassa \& Sahl El-Tina than those in Wadi El-Raiyan \& Belkas ponds. Salinity increased in accordance with salinity of the origin soil rather than pond organic matter. Total carbon, organic carbon and total nitrogen concentrations showed the same trend of nutrients and metals. Carbon: nitrogen ratio values differ $(P<0.05)$ among ponds of the four farms tested. The results revealed that pond organic matter influence the chemical composition of pond sediments. Pond bottom management practices included drying of pond bottoms between crops, liming and periodic sediment removal have to be performed use by producers to maintain relatively good bottom quality especially in old ponds (Abbassa \& Sahl El-Tina). Pond sediments of this study generally had favourable quality for use in aquaculture.
\end{abstract}

Key words: chemical characteristics, bottom sediment, fish ponds, organic matter.

\section{INTRODUCTION}

Fish aquaculture is a prominent industrial activity in Egypt. The fish production in Egypt depends largely on fish farming which present about $62 \%$ of the total production. The fish culture area is widely extended and received water from the River Nile and irrigation drainage water. The main cultured species are tilapia, mullets and catfish.

Fish production, in aquaculture, is characterized by high loads of organic matter in the form of feed and/or organic fertilizers. As a result, organic matter accumulates on pond soils over time. Uneaten feed, senescent phytoplankton and fish feces are the principal sources of wastes from fish production activities (Wudtisin \& Boyd 2006). 
Whereas accumulation of inorganic solids physically interferes with fish harvest, accumulation of organic matter has an important effect on sediment composition (changing both physical and chemical characteristics) and acts as metal trap. Excessive amounts of organic matter in pond soils can result in deterioration of pond bottom condition and have negative effects on the survival and growth of aquatic animals (Boyd 1995). Also, these materials are rich in nitrogen and phosphorus that can readily be converted to forms available for algal growth, thus they have a potential to alter the trophic state of the pond water. Organic matter, phosphorous along with nitrogen compounds and metals are the most significant chemicals related to pollution from aquaculture facilities (Carbonell et al., 1998). They may reflect changes in the environmental conditions over a long period of time.

With the accumulation of organic matter, the oxygen demand increases and oxygen depletion in the sediments may occur. When anaerobic conditions develop in the pond bottom, fish growth is adversely affected because of the formation of toxic substances such as ammonia, nitrite and hydrogen sulfide (Tepe \& Boyd 2002). Phytoplankton is considered the major source of organic matter in aquaculture ponds (Boyd 1995). Schroeder et al. (1991) found that as much as $50 \%$ of the algal standing crop settles on the sediment surface each day.

Soils are a major factor in pond aquaculture, because pond bottoms affect water quality and production. Concentrations of both nutrients and phytoplankton productivity in pond waters are related to $\mathrm{pH}$ and nutrient concentrations in soils (Boyd 1995). He also mentioned that, the composition of culture pond soils is altered by residues from feeds and fertilizers, settling of dead plankton, and accumulation of sediment and salts. Nguyena et al. (2005) declared that sediments provide a temporally integrated indication of the aquatic environment condition and act as a major reservoir for metals. The general opinion is that water quality deterioration is related to a decline in pond bottom quality as a result of sediment accumulation (Tepe \& Boyd, 2002).

The accumulation of soft sediment in the deeper areas of ponds became problematic after 15-20 years of continuous culture (Wudtisin \& Boyd, 2006). Accumulations of carbon, nitrogen and phosphorus in fish pond soils have been reported by several researchers (Fishar \& Abdel-Regal, 1998, Ritvo et al., 2002, Tepe \& Boyd, 2002, Thunjai et al., 2004, Wudtisin \& Boyd 2006). Munsiri et al. (1996) reported a higher concentration of nutrients in soils of older shrimp ponds than in those of newer ones.

Sediment quality is a good indicator of pollution in water column, where it tends to concentrate the heavy metals and other organic pollutants. Metals concentrations in 
sediments depend primarily upon the nature of the input sources. Metals may be released by redox-processes and move up to the water column leading to the exposure of aquatic organisms (Qari et al., 2005).

The present study was conducted to evaluate pond bottom quality in ponds used for fish production. The chemical properties $(\mathrm{pH}$, nutrients, major ions and salinity) and distribution of some metals ( $\mathrm{Fe}, \mathrm{Zn}, \mathrm{Cu}, \mathrm{Mn}, \mathrm{Cd}$ and $\mathrm{Pb}$ ) in sediments from different aquaculture fish ponds in relation to soil texture and organic content were investigated.

\section{MATERIALS AND METHODS}

\section{Sampling}

Soil samples were collected from four fish farms, Abbassa, Sahl El-Tina, Wadi ElRaiyan and Belkas situated in regions namely, Sharkia, Port Saeed, Fayoum and Dakahlia Governorate, respectively. Sampling of bottom sediments (at the upper 10 $\mathrm{cm}$ ) were carried out from 3 fish ponds (at multiple points) at each farm during the culture season of the year 2007 using Peterson grab as described in (Boyd \& Tucker, 1992) and kept in cleaned plastic bags. The wet sediment samples were air dried, pulverized, and then combined within ponds and mixed to provide a homogeneous mixture. Three sediment replicate samples from each site were combined.

Soil analysis

Soil $\mathrm{pH}$ was measured with a glass electrode of a digital $\mathrm{pH}$ meter (Model 25, Fisher Scientific) inserted into a 1:1 mixture of dry, pulverized soil and distilled water. Organic matter was measured as loss on ignition at $550^{\circ} \mathrm{C}$ for $3 \mathrm{~h}$ (Page et al., 1982), while organic carbon (OC \%) was calculated from organic matter (OM) data using the conventional conversion: $\mathrm{OM}=1.7 \times \mathrm{OC}$ (Boyd, 1995). Free carbonate $\left(\% \mathrm{CaCO}_{3}\right)$ was measured by neutralization of $\mathrm{CaCO}_{3}$ with $0.5 \mathrm{~N} \mathrm{H}_{2} \mathrm{SO}_{4}$ (Jackson, 1958).

Total phosphorus (TP) was determined colorimetrically with ascorbic acid reduction method after ignition (at $500^{\circ} \mathrm{C}$ for $4 \mathrm{~h}$ ) and digestion with $\mathrm{H}_{2} \mathrm{SO}_{4}$ and $\mathrm{HNO}_{3}$ (APHA, 1985, Boyd \& Tucker 1992). Inorganic phosphorus (IP) was extracted as total $P$ without ignition, while organic phosphorus (OP) was calculated from the difference between TP and IP.

Electric conductivity (EC), total dissolved solids (TDS) and salinity were measured in (1:5) soil-distilled water extract using a salinity-conductivity meter (model, YSI EC 300). Soluble ions $\left(\mathrm{HCO}_{3}\right.$-alkalinity, $\mathrm{Ca}^{++}, \mathrm{Cl}^{-}$and $\mathrm{SO}_{4}-\mathrm{S}$ ) were measured in (1:5) soil-distilled water extract by the methods reported in APHA (1985) and Boyd \& Tucker (1992). Total nitrogen was measured by kjeldahl method, while 
inorganic $\mathrm{N}\left(\mathrm{NO}_{2}-\mathrm{N} \& \mathrm{NO}_{3}-\mathrm{N}\right)$ was extracted with $2 \mathrm{M} \mathrm{KCl}$ and analyzed by cadmium reduction method (Page et al., 1982).

Metals in sediment samples were extracted as described in Page et al. (1982). Atomic Absorption Spectrophotometer instrument (Model Thermo Electron Corporation, S. Series AA Spectrometer with Gravities furnace, UK) was used to detect the heavy metals concentrations as $\mu \mathrm{g} / \mathrm{g}$ dry weight.

\section{Statistical analysis}

One-way ANOVA and Duncan multiple range test were used to evaluate the significant difference of the concentration of different variables studied with respect to different farms. Regression analysis was also performed for the relationship among different variables. A probability at level of 0.05 or less was considered significant (Bailey, 1981).

\section{RESULTS AND DISCUSSION}

\section{pH and organic matter}

The sediment $\mathrm{pH}$ of the fish ponds is considered one of the most important factors made to determine bottom pond soil, characteristics, processes and productivity. In addition $\mathrm{pH}$ is essential in order to evaluate the expected solubility and availability of phosphates (Thomas, 1996).

Soils of the different farms are slightly basic and showed a slight variation in $\mathrm{pH}$ values. Sediment $\mathrm{pH}$ lies in the alkaline side and its values ranged between 7.67 in Wadi El-Raiyan ponds to 8.25 in Belkas ponds and the average pH values showed significant difference $(P<0.05)$ among the four types of ponds (Table 1$)$. The optimum $\mathrm{pH}$ range for aquaculture pond sediments is $7.5-8.0$ because microbial activity is most rapid in this $\mathrm{pH}$ range (Boyd \& Pipoppinyo 1994). Microbial decomposition of organic matter recycles nutrients and prevents accumulation of organic matter in pond bottoms. The water supply used to fill and maintain water levels in ponds contains high values of total alkalinity. Bases from the water supply may be the reason for increasing the $\mathrm{pH}$ of the sediment of the studied ponds. Also, age of ponds soil, organic matter and clay content of soil play a role in $\mathrm{pH}$ values of different ponds. It is possible that soils in the area where the young and sandy sediments (Belkas) were built had a naturally higher $\mathrm{pH}$ than the area for the other ponds. 
Table 1. Overall means $\pm \mathrm{SE}$ of $\mathrm{pH}$, total alkalinity and organic matter in pond sediments of the studied farms.

\begin{tabular}{|c|c|c|c|}
\hline Site & Variables & T. alkalinity mg/g & OM \% \\
\hline Abbassa & $7.84^{\mathrm{b}} \pm 0.05$ & $1.42^{\mathrm{ab}} \pm 0.30$ & $5.88 \pm 0.09^{\mathrm{a}}$ \\
\hline Sahl El-Tina & $7.74^{\mathrm{b}} \pm 0.12$ & $0.52^{\mathrm{b}} \pm 0.04$ & $5.89 \pm 0.19^{\mathrm{a}}$ \\
\hline Wadi El-Raiyan & $7.72^{\mathrm{b}} \pm 0.06$ & $1.65^{\mathrm{a}} \pm 0.32$ & $3.71 \pm 0.33^{\mathrm{b}}$ \\
\hline Belkas & $8.25^{\mathrm{a}} \pm 0.04$ & $0.55^{\mathrm{b}} \pm 0.05$ & $1.37 \pm 0.30^{\mathrm{c}}$ \\
\hline
\end{tabular}

Means indicated by different letters differed $(P<0.05)$ as determined by Duncan's multiple range test, vertical comparisons only. Each number is the average of three ponds.

Soil $\mathrm{pH}$ showed an opposite trend with the percent of organic matter, that recorded the highest values (5.88) in Abbassa and (5.89) in Sahl El-Tina farms, the lowest value (1.37) was recorded in Belkas farm. This may be due to large inputs of organic matter from feed and organic fertilizers which enrich the primary production at Abbassa and Sahl El-Tina farms which are older than Wadi El-Raiyan and Belkas farms.

Phytoplankton is considered the major source of organic matter in aquaculture ponds (Boyd 1995). Also, the decrease in soil pH of Abbassa and Sahl El-Tina ponds may be related to the high sediment clay content of these ponds. Ritvo et al. (2003) mentioned that soil $\mathrm{pH}$ decrease as clay content increase. They also added that the $\mathrm{pH}$ of the old ponds was lower than the $\mathrm{pH}$ of ponds that had been used for more than one production cycle. The same trend was reported by Fishar \& Abdel-Regal (1998) in fish ponds at El-Fayoum Governorate.

The sediments showed variation in total alkalinity concentration with higher values in Abbassa and Wadi El-Raiyan and lower ones in Sahl El-Tina and Belkas as shown in table (1). Variation in alkalinity may be related to the bicarbonate content which comes with agriculture drainage water that fed these ponds.

\section{Carbon and Nitrogen}

Total carbon (TC) concentrations recorded no differences among the three farms, Abbassa, Sahl El-Tina and Wadi El-Raiyan, while the lowest value occurred in Belkas farm sediment (Table 2). Concentrations of total carbon ranged from 5.03\% (Belkas ponds) to $9.01 \%$ (Wadi El-Raiyan ponds). Abbassa ponds were closer to Sahl El-Tina ponds with respect to total carbon concentration as they are of nearly the same organic matter content, whereas Belkas pond sediment showed the lowest value of organic matter content as it is a young ponds. Carbon accumulated in pond bottoms as a result of the deepening of sediment over time rather than by the development of a high carbon concentration in surface sediment Ritvo et al. (2002). 
Table 2. Overall means $\pm \mathrm{SE}$ of $\mathrm{TC}, \mathrm{OC}$, In $\mathrm{C}$, carbonate, $\mathrm{TN}$ and $\mathrm{C} / \mathrm{N}$ ratio in pond sediments of the studied farms.

\begin{tabular}{|c|c|c|c|c|}
\hline Variables & Abbassa & Sahl El-Tina & $\begin{array}{l}\text { Wadi El- } \\
\text { Raiyan }\end{array}$ & Belkas \\
\hline Total carbon (\%) & $9.01^{\mathrm{a}} \pm 0.58$ & $8.72^{a} \pm 0.09$ & $8.66^{\mathrm{a}} \pm 0.83$ & $5.03^{b} \pm 0.32$ \\
\hline $\begin{array}{c}\text { Organic carbon } \\
(\%)\end{array}$ & $3.46^{\mathrm{a}} \pm 0.05$ & $3.47^{\mathrm{a}} \pm 0.11$ & $2.18^{\mathrm{b}} \pm 0.19$ & $0.80^{c} \pm 0.18$ \\
\hline $\begin{array}{c}\text { Carbonate (\% } \\
\text { CaCO3) }\end{array}$ & $46.25^{b} \pm 2.32$ & $43.75^{b} \pm 0.72$ & $54^{\mathrm{a}} \pm 2.38$ & $35.25^{\complement} \pm 1.66$ \\
\hline $\begin{array}{c}\text { Inorganic carbon } \\
(\%) \\
\end{array}$ & $5.55^{\mathrm{b}} \pm 0.28$ & $5.25^{\mathrm{b}} \pm 0.09$ & $6.48^{\mathrm{a}} \pm 0.29$ & $4.23^{c} \pm 0.20$ \\
\hline $\begin{array}{c}\text { Total Nitrogen } \\
(\%)\end{array}$ & $0.20^{\mathrm{a}} \pm 0.01$ & $0.13^{\mathrm{bc}} \pm 0.01$ & $0.18^{\mathrm{ab}} \pm 0.02$ & $0.11^{\mathrm{c}} \pm 0.01$ \\
\hline $\mathrm{C} / \mathrm{N}$ ratio & $17.61^{\mathrm{b}} \pm 1.06$ & $26.03^{\mathrm{a}} \pm 3.42$ & $12.01^{\mathrm{b}} \pm 3.06$ & $7.19^{b} \pm 4.49$ \\
\hline
\end{tabular}

Abbreviations as in table 1 , horizontal comparisons only.

Organic carbon (OC) concentration ranged from $0.80 \%$ to $3.47 \%$. Abbassa and Sahl El-Tina ponds were similar and had a higher average organic carbon concentration $(\mathrm{P}<0.05)$ than Wadi El-Raiyan or Belkas ponds (Table 2$)$. Belkas ponds had the lowest average organic carbon concentration. Aquaculture pond sediments may contain more than 3\% organic carbon (Boyd, 1995). The optimum range of organic carbon in pond sediments is 1-3\% (Banerjea 1967). Lower concentrations of organic carbon are unfavourable for the growth of benthic organisms that are important food for many fish species and higher concentrations favour anaerobic conditions at the sediment-water interface. Concentrations of organic carbon in old ponds of high organic matter content (Abbassa and Sahl El-Tina) were higher than in younger ponds (Wadi El-Raiyan and Belkas) of lower organic matter content. Carbon accumulates in sediment over time as a result of fertilizer and feed inputs (Tepe \& Boyd 2002).

The carbonate (as $\left.\mathrm{CaCO}_{3}\right)$ and inorganic carbon were the highest $(\mathrm{P}<0.05)$ in sediments of Wadi El-Raiyan. This may be related to the increase of fine sand sediments in this farm. There were no differences between Abbassa and Sahl El-Tina, while Belkas sediment had the lowest percentage (Table 2).

The total nitrogen (TN) concentration ranged from 0.11 to $0.20 \%$ (Table 2). A significant difference $(P<0.05)$ occurred among the four farms with the highest value recorded in Abbassa, while the lowest one was observed in Belkas sediment. The high sediment clay content and age of Abbassa ponds play a role in increase of TN. Tepe \& Boyd (2002) mentioned that TN increase as clay particles increase in sediments. 
The $\mathrm{C} / \mathrm{N}$ ratio of organic matter has been widely used as index of the rate at which organic matter will decompose. A low C/N ratio (e.g. 10) favors more rapid and complete decomposition of soil organic matter than does for a high $\mathrm{C} / \mathrm{N}$ ratio (e.g. 80) (Boyd 1995). In the present study, the highest $\mathrm{C} / \mathrm{N}$ ratios were recorded in pond sediments at Sahl El-Tina, while the lowest ones were recorded at Belkas followed by Wadi El-Raiyan pond sediments (Table, 2), which were near the favorable levels in relation to fish production. In this connection, Boyd (1995) reported that the most favorable $\mathrm{C} / \mathrm{N}$ ratio in relation to fish production is $10-15$. Wudtisin \& Boyd (2006) mentioned that carbon to nitrogen $(\mathrm{C} / \mathrm{N})$ ratios usually were between 20 and 50 . In the present study the carbon to nitrogen $(\mathrm{C} / \mathrm{N})$ ratios ranged between 7.19 and 26.03 which were greater than $\mathrm{C} / \mathrm{N}$ ratios of 5 to 10 for research ponds used for channel catfish culture at Auburn, Alabama (Munsiri et al. 1995). Tilapia ponds in Thailand had an average total nitrogen concentration of $0.19 \%$ and a carbon: nitrogen ratio of 11 (Thunjai et al. 2004). The accumulation of organic matter in Sahl El-Tina sediments may be due to the high $\mathrm{C} / \mathrm{N}$ ratio followed by Abbassa, Wadi El-Raiyan then Belkas farm.

\section{Phosphorus}

Total phosphorus concentration averaged 1047.04, 1124.79, 643.84 and 465.61 $\mu \mathrm{g} / \mathrm{g}$ in Abbassa, Sahl El-Tina, Wadi El-Raiyan and Belkas pond sediments, respectively (Table 3). Concentrations of total phosphorus generally increased in Sahl El-Tina followed by Abbassa which characterized by high organic matter.

Table 3. Overall means \pm SE of TP, IP and OP in pond sediments of the studied farms.

\begin{tabular}{|c|c|c|c|c|}
\hline Variables & Abbassa & $\begin{array}{c}\text { Sahl } \\
\text { El-Tina }\end{array}$ & $\begin{array}{c}\text { Wadi } \\
\text { El-Raiyan }\end{array}$ & Belkas \\
\hline \multirow{2}{*}{ TP } & $1047.04^{\mathrm{a}} \pm$ & $1124.79^{\mathrm{a}} \pm$ & $643.84^{\mathrm{b}} \pm$ & $465.61^{\mathrm{b}} \pm$ \\
& 187.49 & 275.54 & 38.62 & 92.11 \\
\hline \multirow{2}{*}{ In P } & $412.22^{\mathrm{a}} \pm$ & $392.58^{\mathrm{a}} \pm$ & $308.89^{\mathrm{a}} \pm$ & $203.27^{\mathrm{b}} \pm$ \\
& 49.56 & 46.22 & 32.54 & 27.60 \\
\hline OP & $610.73^{\mathrm{a}} \pm$ & $732.22^{\mathrm{a}} \pm$ & $334.95^{\mathrm{a}} \pm$ & $262.34^{\mathrm{a}} \pm$ \\
& 293.34 & 183.26 & 9.13 & 142.38 \\
\hline
\end{tabular}

Abbreviations as in table 1, horizontal comparisons only.

It was assumed that most phosphorus in pond sediment was bound inorganically in iron, aluminum, and calcium phosphates (Boyd, 1995). This assumption was made because most terrestrial soils contain only $25-50 \%$ of phosphorus in organic combination (Sharpley, 2000). In this study, inorganic 
phosphorus concentrations averaged between 203.27 and $412.22 \mu \mathrm{g} / \mathrm{g}$, while the averages for organic phosphorus ranged between 262.34 and $732.22 \mu \mathrm{g} / \mathrm{g}$ (Table 3).

The average percentages of phosphorus were $52.93 \%$ and $47.07 \%$ in organic and inorganic combination, respectively. Thus, most of the phosphorus in all pond sediments was organically bound, and the proportion of organically bound to inorganically bound phosphorus increase as organic matter increase. Organic phosphorus generally comprises a higher proportion of the total phosphorus in aquaculture pond sediment (Tepe \& Boyd 2002, Wudtisin \& Boyd 2006). They also added that phosphorus accumulates in sediment over time as a result of fertilizer and feed inputs. Because of the near neutral $\mathrm{pH}$, phosphorus availability from the sediment is relatively high.

Moderate to high phosphorus concentrations in pond sediments favour greater fish production (Banerjea 1967). Nevertheless, if pond sediments become saturated with phosphorus, they will no longer remove phosphorus from pond water.

\section{Salinity}

Sediment salinity as a measurement of EC, TDS and salinity in the sediment extracts ranged from $0.83 \mathrm{~g} / \mathrm{kg}$ in Abbassa farm to $40.50 \mathrm{~g} / \mathrm{kg}$ in Sahl El-Tina farm (Table 4). EC and TDS followed the same trend of salinity. The results showed that salinity varied related to the natural soil salinity in each farm rather than soil organic matter. The increase in sediment salinity in fish ponds of Sahl El-Tina may be related to the increase in sodium salts in these sediments.

Table 4. Overall means \pm SE of EC, Salinity and TDS in pond sediments of the studied aquaculture farms.

\begin{tabular}{|c|c|c|c|}
\hline Variables Site & $\begin{array}{c}\text { Salinity } \\
\mathrm{g} / \mathrm{kg}\end{array}$ & $\begin{array}{c}\text { EC } \\
\mathrm{mmohs} / \mathrm{cm}\end{array}$ & $\begin{array}{c}\text { TDS } \\
\mathrm{g} / \mathrm{kg}\end{array}$ \\
\hline Abbassa & $0.83^{\mathrm{b}} \pm 0.17$ & $1.67^{\mathrm{b}} \pm 0.34$ & $1.07^{\mathrm{b}} \pm 0.24$ \\
\hline Sahl El-Tina & $40.50^{\mathrm{a}} \pm 12.00$ & $69.32^{\mathrm{a}} \pm 18.88$ & $45.13^{\mathrm{a}} \pm 12.29$ \\
\hline Wadi El-Raiyan & $1.67^{\mathrm{b}} \pm 0.17$ & $3.14^{\mathrm{b}} \pm 0.15$ & $2.49^{\mathrm{b}} \pm 0.54$ \\
\hline Belkas & $3.83^{\mathrm{b}} \pm 1.36$ & $7.91^{\mathrm{b}} \pm 2.36$ & $5.16^{\mathrm{b}} \pm 1.72$ \\
\hline
\end{tabular}

Abbreviations as in table 1 , vertical comparisons only.

\section{Major ions and inorganic nitrogen}

Table (5) shows that, Sahl El-Tina had the highest values of calcium. On the other hand, the concentration of calcium was statistically the same in Abbassa, Wadi El-Raiyan and Belkas farm. Chloride and sulfate ions followed the same trend of calcium ions. Concentrations of calcium, chloride and sulfate showed higher values in Sahl El-Tina ponds which had higher values of salinity than the other ponds (Table 5). 
This may be attributed to the fact that these ponds were constructed on soils with higher salinity that contains great values of calcium concentration.

Table 5. Overall means \pm SE of major ions, $\mathrm{Ca}++, \mathrm{Cl}-$, SO4-S, NO2-N and NO3-N in pond sediments of the studied farms.

\begin{tabular}{|c|c|c|c|c|c|}
\hline \multirow{2}{*}{ Site Variables } & $\begin{array}{c}\mathrm{Ca}^{++} \\
\mathrm{mg} / \mathrm{g}\end{array}$ & $\begin{array}{c}\mathrm{Cl}^{-} \\
\mathrm{mg} / \mathrm{g}\end{array}$ & $\begin{array}{c}\mathrm{SO}_{4}-\mathrm{S} \\
\mathrm{mg} / \mathrm{g}\end{array}$ & $\begin{array}{c}\mathrm{NO}_{2}-\mathrm{N} \\
\mu \mathrm{g} / \mathrm{g}\end{array}$ & $\begin{array}{c}\mathrm{NO}_{3}-\mathrm{N} \\
\mu \mathrm{g} / \mathrm{g}\end{array}$ \\
\hline \multirow{2}{*}{ Abbassa } & $\begin{array}{c}0.41^{\mathrm{b}} \pm \\
0.01\end{array}$ & $\begin{array}{c}0.63^{\mathrm{b}} \pm \\
0.13\end{array}$ & $\begin{array}{c}2.78 .49^{\mathrm{b}} \pm \\
0.24\end{array}$ & $\begin{array}{c}0.40^{\mathrm{a}} \pm \\
0.04\end{array}$ & $\begin{array}{c}14.82^{\mathrm{a}} \pm \\
2.49\end{array}$ \\
\hline \multirow{2}{*}{ Sahl El-Tina } & $7.72^{\mathrm{a}} \pm$ & $39.08^{\mathrm{a}} \pm$ & $135.82^{\mathrm{a}} \pm$ & $0.43^{\mathrm{a}} \pm$ & $13.33^{\mathrm{a}} \pm$ \\
& 0.48 & 12.19 & 12.23 & 0.03 & 2.32 \\
\hline \multirow{2}{*}{ Wadi El-Raiyan } & $0.50^{\mathrm{b}} \pm$ & $0.97^{\mathrm{b}} \pm$ & $9.22^{\mathrm{b}} \pm$ & $0.38^{\mathrm{a}} \pm$ & $9.02^{\mathrm{ab}} \pm$ \\
& 0.06 & 0.24 & 2.91 & 0.03 & 0.90 \\
\hline \multirow{2}{*}{ Belkas } & $1.30^{\mathrm{b}} \pm$ & $3.60^{\mathrm{b}} \pm$ & $13.83^{\mathrm{b}} \pm$ & $0.36^{\mathrm{a}} \pm$ & $5.65^{\mathrm{b}} \pm$ \\
& 0.20 & 0.83 & 2.22 & 0.00 & 0.73 \\
\hline
\end{tabular}

Abbreviations as in table 1, vertical comparisons only.

$\mathrm{NO}_{2}-\mathrm{N}$ concentration showed no differences among sediments of the four farms $(\mathrm{P}>0.05)$ (Table 5). $\mathrm{NO}_{3}-\mathrm{N}$ concentration did not differ between Abbassa and Sahl ElTina sediments, however they had greater values than the other two farms (Table 5). In this study, the higher organic matter in the sediment results in higher nitrate concentration. It could explain the observed increase in $\mathrm{NO}_{3}-\mathrm{N}$ over time in the present study.

An increase in soil nutrients concentrations was observed for all nutrient analyzed. The inputs of feed and fertilizers, biological retention by fish or other living organisms and nutrient retention by soil have different effects on the nutrients balance of ponds (Ritvo et al. 2002). In this study, the nutrients loading into the pond sediments increase as clayey texture sediment and the amount of feed and fertilizers applied to ponds (old pond increased). Ritvo et al. (2002) mentioned that eighty-three percent of the change in soil nitrate in shrimp ponds had due to the number of production cycles and clay percentage. Thus, it is possible that nitrogen originating from feed and fertilizers in the current study had been accumulated in the sediment over time. Munsiri et al. (1995) and Tepe \& Boyd (2002) found that concentrations of several sediment quality variables increased over time.

The correlations between different variables in each farm and all ponds were illustrated in table (6). There was a negative correlation between sediment $\mathrm{pH}$ and organic matter content $(r=-0.782, P<0.003)$. The association between soil $\mathrm{Ca}$ concentration and sediment carbonate content was observed in Abbassa, Sahl El-Tina 
and Belkas sediments. The relationship between calcium concentration and salinity, salinity and sulfate is positive and significant. The relationships were positive between OM concentration and TP $(r=0.643, P<0.024)$, OM and OP $(r=0.848, P<0.004)$. A study of tilapia, carp and catfish pond sediments in Arkansas also revealed that total phosphorus concentrations increased as ponds organic matter increased (Tepe \& Boyd 2002). The correlations were high between $O M$ and TN $(r=0.565, P<0.003)$ and $O M$ and $\mathrm{NO}_{3}-\mathrm{N}(\mathrm{r}=0.793, \mathrm{P}<0.002)$.Similar results were obtained by many authors (Ritvo et al. 2003, Tepe \& Boyd 2002, Wudtisin \& Boyd 2006).

Table 6. Correlation between different variables.

\begin{tabular}{|c|c|c|c|c|c|c|c|c|c|c|}
\hline \multirow[b]{2}{*}{ Items } & \multicolumn{2}{|c|}{ Abbassa } & \multicolumn{2}{|c|}{ Sahl El-Tina } & \multicolumn{2}{|c|}{ Wadi El-Raiyan } & \multicolumn{2}{|c|}{ Belkas } & \multicolumn{2}{|c|}{ All ponds } \\
\hline & $r$ & $\mathrm{p}$ & $r$ & $\mathrm{p}$ & $r$ & $p$ & $r$ & $\mathrm{p}$ & $r$ & $p$ \\
\hline $\mathrm{pH} \& \mathrm{OM}$ & -0.518 & 0.002 & -0.512 & 0.031 & -0.125 & 0.421 & 0.138 & 0.514 & -0.782 & 0.003 \\
\hline $\mathrm{pH} \& \mathrm{CO}_{3}$ & 0.654 & 0.004 & 0.676 & 0.021 & -0.246 & 0.425 & 0.882 & 0.005 & -0.612 & 0.010 \\
\hline $\mathrm{Ca}^{++} \& \mathrm{CO}_{3}$ & 0.652 & 0.012 & 0.707 & 0.001 & 0.297 & 0.083 & 0.514 & 0.016 & 0.175 & 0.086 \\
\hline Salinity\&Ca ${ }^{++}$ & 0.250 & 0.103 & 0.937 & 0.000 & 0.750 & 0.001 & 0.976 & 0.000 & 0.933 & 0.000 \\
\hline Salinity\& $\mathrm{SO}_{4}^{--}$ & 0.218 & 0.075 & 0.931 & 0.000 & 0.855 & 0.000 & 0.907 & 0.000 & 0.930 & 0.000 \\
\hline OM \& TP & 0.913 & 0.000 & 0.988 & 0.000 & 0.909 & 0.000 & 0.937 & 0.000 & 0.643 & 0.024 \\
\hline $\mathrm{OM} \& \mathrm{OP}$ & 0.862 & 0.002 & 0.997 & 0.000 & 0.995 & 0.000 & 0.935 & 0.000 & 0.848 & 0.004 \\
\hline OM \& IP & 0.484 & 0.151 & 0.621 & 0.039 & 0.978 & 0.001 & 0.283 & 0.083 & 0.487 & 0.252 \\
\hline OM\&TN & 0.650 & 0.002 & 0.878 & 0.001 & 0.982 & 0.000 & 0.745 & 0.039 & 0.565 & 0.003 \\
\hline $\mathrm{OM}_{2} \mathrm{NO}_{3}-\mathrm{N}$ & 0.841 & 0.002 & 0.948 & 0.000 & 0.832 & 0.000 & 0.511 & 0.061 & 0.793 & 0.002 \\
\hline $\mathrm{OM} \& \mathrm{NO}_{2}$ & 0.799 & 0.032 & 0.542 & 0.017 & 0.793 & 0.011 & 0.244 & 0.074 & 0.315 & 0.122 \\
\hline TC\&OC & 1.000 & 0.000 & 1.000 & 0.000 & 1.000 & 0.000 & 1.000 & 0.000 & 0.882 & 0.000 \\
\hline
\end{tabular}

\section{Heavy metals}

Heavy metals are accumulated in sediments, where they are incorporated in several biological and chemical cycles, affecting the water column and biota. On the other hand, chemical reactions can change the concentration of heavy metals in sediments and, as a consequence, in the overlying water (Qari et al., 2005).

The average concentrations of metals differ among sediments from the four types of aquaculture ponds and detected in the following order: $\mathrm{Fe}>\mathrm{Mn}>\mathrm{Zn}>\mathrm{Cu}>$ $\mathrm{Pb}>\mathrm{Cd}$ (Table 7). Sampling results showed that fish farms which are characterized by having high values of organic matter content accumulate high levels of metals. Fine sediments associated with high load of organic matter have a larger surface area, which allows heavy metals and other contaminants to be adsorbed easily Nguyena et al. (2005). 
Table 7. Overall means $(\mu \mathrm{g} / \mathrm{g}$ dry wt.) \pm SE of studied metals in pond sediments of the studied farms.

\begin{tabular}{|c|c|c|c|c|}
\hline Metal & Abbassa & Sahl El-Tina & Wadi El-Raiyan & Belkas \\
\hline $\mathrm{Fe}$ & $6741.33^{\mathrm{ab}} \pm 249.85$ & $9216.45^{\mathrm{a}} \pm 1280.63$ & $4388.94^{\mathrm{bc}} \pm 1168.05$ & $2129.16^{\mathrm{c}} \pm 267.10$ \\
\hline $\mathrm{Zn}$ & $145.88^{\mathrm{a}} \pm 1.57$ & $104.07^{\mathrm{b}} \pm 9.18$ & $64.83^{\mathrm{c}} \pm 7.29$ & $46.61^{\mathrm{c}} \pm 4.53$ \\
\hline $\mathrm{Cu}$ & $22.38^{\mathrm{a}} \pm 2.29$ & $26.52^{\mathrm{a}} \pm 1.20$ & $6.88^{\mathrm{b}} \pm 0.59$ & $10.56^{\mathrm{b}} \pm 2.34$ \\
\hline $\mathrm{Mn}$ & $795.38^{\mathrm{a}} \pm 58.65$ & $756.81^{\mathrm{a}} \pm 34.72$ & $86.25^{\mathrm{c}} \pm 11.76$ & $233.12^{\mathrm{b}} \pm 38.78$ \\
\hline $\mathrm{Cd}$ & $0.00^{\mathrm{b}} \pm 0.00$ & $0.03^{\mathrm{b}} \pm 0.003$ & $0.70^{\mathrm{a}} \pm 0.10$ & $0.75^{\mathrm{a}} \pm 0.21$ \\
\hline $\mathrm{Pb}$ & $2.71^{\mathrm{a}} \pm 0.76$ & $0.00^{\mathrm{b}} \pm 0.00$ & $0.13^{\mathrm{b}} \pm 0.13$ & $0.00^{\mathrm{b}} \pm 0.00$ \\
\hline $\mathrm{T}$. ave. & 7707.68 & 10103.87 & 4547.72 & 2410.19 \\
\hline
\end{tabular}

Abbreviations as in table 1, horizontal comparisons only.

On the other hand, the lowest abundance of metals was observed in Wadi ElRaiyan and Belkas farms which showed low levels of organic matter content, which means that the present level of organic matter content is limiting factor for the distribution of metals. The distributions of metals are associated mainly with the organic matter fraction of the sediment (Saeed \& Shaker, 2008).

There was a significant positive correlation $(P<0.05)$ between each of $\mathrm{Fe}, \mathrm{Zn}, \mathrm{Cu}$ and $\mathrm{Mn}$ and organic matter (Table 8). On the other hand $\mathrm{Cd}$ exhibit a negative correlation, while $\mathrm{Pb}$ showed no correlation $(\mathrm{P}>0.05)$ with organic matter content. The trace metals $\mathrm{Cu}$ and $\mathrm{Zn}$ show significant correlations with $\mathrm{Mn}$ and $\mathrm{Fe}$ as presented in table (8). This may reflect the variability of the fine sediment fraction in the bottom sediments as mentioned by Nguyena et al. (2005).

Table 8. Correlation between different metals and organic matter.

\begin{tabular}{|c|c|c|c|c|c|}
\hline Variables & $\mathrm{r}$ & $\mathrm{P}$ & Variables & $\mathrm{r}$ & $\mathrm{P}$ \\
\hline Fe\&Zn & 0.729 & 0.007 & OM \& Fe & 0.875 & 0.000 \\
\hline Fe\&Cu & 0.750 & 0.005 & OM \& Zn & 0.866 & 0.000 \\
\hline Fe\&Mn & 0.729 & 0.007 & OM \& Cu & 0.738 & 0.006 \\
\hline Cu\&Mn & 0.962 & 0.000 & OM \& Mn & 0.795 & 0.002 \\
\hline Zn\&Mn & 0.844 & 0.000 & OM \& Cd & -0.849 & 0.000 \\
\hline Fe\&Cd & -0.804 & 0.002 & OM \& Pb & 0.476 & 0.1177 \\
\hline
\end{tabular}

$r$ : correlation coefficient, $P$ : level of significance ( $r$ is significant at $P=$ or $<0.05$ ).

The relations between $\mathrm{OM}$ and each of $\mathrm{Fe}, \mathrm{Zn}, \mathrm{Cu}, \mathrm{Mn}, \mathrm{Cd}$, and $\mathrm{Pb}$ in sediments of the four farms were ( $r=0.8581$ in Sahl El-Tina, $r=0.9732$ in Abbassa, $r=0.9963$ in Belkas and $r=0.9118$ in Wadi El-Raiyan) for Fe, $(r=0.4031$ in Sahl El-Tina, $r=0.9170$ in Abbassa, $r=0.3842$ in Belkas and $r=0.9667$ in Wadi El-Raiyan) for $Z n,(r=0.8802$ 
in Sahl El-Tina, $r=0.3676$ in Abbassa, $r=0.2686$ in Belkas and $r=0.6389$ in Wadi ElRaiyan) for $\mathrm{Cu}$, $(r=0.8298$ in Sahl El-Tina, $r=0.4011$ in Abbassa, $r=0.2899$ in Belkas and $r=0.8302$ in Wadi El-Raiyan) for $\mathrm{Mn},(r=0.594$ in Sahl El-Tina, $r=0.1011$ in Abbassa, $r=0.1855$ in Belkas and $r=0.1756$ in Wadi El-Raiyan) for $\mathrm{Cd}$ and $(r=0.157$ in Sahl El-Tina, $r=0.4004$ in Abbassa, $r=0.2311$ in Belkas and $r=0.7043$ in Wadi ElRaiyan) for $\mathrm{Pb}$.

The increases of Fe and $\mathrm{Mn}$ could be attributed to the dissolution of certain Fe and $\mathrm{Mn}$ oxides under reduced condition, which would turn these elements into a more soluble form in the extraction solution used to extract these elements in the present study. Zinc and $\mathrm{Cu}$ accumulation could came from feed as recorded by Wudtisin \& Boyd (2006). They also added that accumulations of $\mathrm{Fe}, \mathrm{Mn}, \mathrm{Cu}$, and $\mathrm{Zn}$ could have occurred by precipitation with hydroxyl ions and carbonates under aerobic conditions. Accumulation of $\mathrm{Fe}$ and $\mathrm{Mn}$ can occur when soluble reduced $\mathrm{Fe}$ and $\mathrm{Mn}$ in the sediment diffuse upward and precipitate again near the oxic layer close to the soil water interface.

This explains the higher concentrations of heavy metals in sediments of these ponds. If the accumulation of heavy metals in the sediments is related to aquaculture activities, it must be accompanied by an accumulation of organic matter (Schendel et al. 2004).

Comparing the metals concentrations in this study (Abbassa and Sahl El-Tina) with those reported for other areas of the world, indicated that, the concentrations detected in this study (except $\mathrm{Pb}$ ) were higher than those reported by (Wudtisin \& Boyd 2006, Tepe \& Boyd 2002) in fish farms. This could be attributed to the fact that sediments in this study were never removed. As with major cations, optimum concentrations of minor elements in pond sediments are not known (Thunjai et al. 2004).

\section{CONCLUSION}

The results reported above suggest that pond organic matter is an important factor determining the quality of bottom sediments. There were differences in sediment quality among sediments of the four pond farms of this study. Increase in the concentrations of $\mathrm{C}, \mathrm{N}, \mathrm{P}, \mathrm{NO}_{2}-\mathrm{N}, \mathrm{NO}_{3}-\mathrm{N}, \mathrm{Fe}, \mathrm{Zn}, \mathrm{Cu}, \mathrm{Mn}$ and $\mathrm{Pb}$ were detected in pond sediments of higher organic matter content than those of lower organic matter content. $\mathrm{Ca}^{++}, \mathrm{Cl}^{-}$and $\mathrm{SO}_{4}-\mathrm{S}$ are mostly correlated with soil salinity than soil organic matter. Differences in major ions are thought to be significant in aquaculture ponds and this may be related to aquaculture inputs and sediment organic matter. Pond sediments of this study generally had favourable quality for use in aquaculture. 


\section{REFERENCES}

1. American Public Health Association (APHA). 1985. Standard methods for the examination of water and wastewater.16 ${ }^{\text {th }}$ ed. Washington, D.C. $1268 \mathrm{pp}$.

2. Bailey, N. T. 1981. Statistical Methods in Biology. $2^{\text {nd }}$ ed. (Biological Science Texts).

3. Banerjea S. M. 1967. Water quality and soil condition of fish ponds in some states of India in relation to fish production. Indian Journal of Fisheries.14, 113-144.

4. Boyd, C. E. and C. S. Tucker. 1992. Water quality and pond soil analysis for aquaculture. Alabama agricultural experimental station. Auburn. Uni. 183 pp.

5. Boyd, C. E. and Pippopinyo, S. 1994. Factors affecting respiration in dry pond bottom soils. Aquaculture 120:283-294.

6. Boyd C. E. 1995. Bottom Soils, Sediment, and Pond Aquaculture. Chapman and Hall, New York, p. 348.

7. Carbonell, G., C. Ramos and J. V. Tarazona. 1998. Metals in shrimp culture areas from the Gulf of Foneseca, Central America. 1. Sediment. Bull. Environ. Cotam. Toxicol. 60: 252-259.

8. Fishar, M. R. and R. M. Abdel-Regal. 1998. Macrobenthic invertebrates in relation to sediment properties in some fish farms. Egypt. J. Aquat. Biol. \& Fish. 2 (2): 87100.

9. Jackson, M. L. 1958. Soil Chemical Analysis. Prentice Hall, Inc., p. 244.

10. Munsiri, P., C. E. Boyd and B. J. Hajek. 1995. Physical and chemical characteristics of bottom soil profiles in ponds at Auburn, Alabama, USA, and a proposed method for describing pond soil horizons. Journal of the World Aquaculture Society. 26:346-377.

11. Munsiri, P., C. E. Boyd, D. Teichert-Coddington and B. F. Hajek. 1996. Texture and chemical composition of soils from shrimp ponds near Choluteca, Honduras. Aquaculture International. 4: 157-1 68.

12. Nguyen, H. L., M. Leermakers, M. Elskens, F. De Ridder, T. H. Doan and W. Baeyens. 2005. Correlations, partitioning and bioaccumulation of heavy metals between different compartments of Lake Balaton. Science of the Total Environment 341: 211- 226.

13. Page, A. L., R. H. Miller and D. R. Kenney. (Eds.). 1982. Methods of Soil Analysis. Part 2, Chemical and Microbiological Properties. Amer. Soc. Agronomy, Madison. $1159 \mathrm{pp}$.

14. Qari R., S. S. Alam and N. A. Qureshi. 2005. A comparative study of heavy metal concentrations in surfacial sediments from coastal areas of Karachi, Pakistan. Mar. Pollu. Bull. , 50: 595-599. 
15. Ritvo, G., V. Shitumbanuma and T. M., Samocha, 2002. Changes in the concentration of nutrients and other chemical properties of shrimp pond soils as a function of pond use. J. World Aqua. Soc. 33: 233-243.

16. Ritvo G., Y.Avnimelech and M. Kochba. 2003. Empirical relationship between conventionally determined $\mathrm{pH}$ and in situ values in waterlogged soils. Aquaculture Engineering. 27: 1-8.

17. Saeed, S. M. and I. M. Shaker. 2008. Assessment of heavy metals pollution in water and sediments and their effect on Oreochromis niloticus in the northern delta lakes, Egypt. The $8^{\text {th }}$ International Symposium on Tilapia in Aquaculture. Cairo, 12-14 October, 2008: 475-488.

18. Schendel, E. K., S. E. Nordstrom and L. M. Lavkulich. 2004. Floc and sediment properties and their environmental distribution from a marine fish farm. Aquac. Res. 35: 483-493.

19. Schroeder G. L., A. Alkon and M. Laher 1991. Nutrient flow in pond aquaculture systems. In: Aquaculture and Water Quality (ed. by D.E. Brune \& J.R. Tomasso), pp. 498-505. World Aquaculture Society, Baton Rouge, LA, USA.

20. Sharpley, A. 2000. Phosphorus availability. Pages D-18 to D-38 in M. E. Sumner, editor. Handbook of soil science. CRC Press, Boca Raton, Florida, USA.

21. Tepe, Y. and C. Boyd. 2002. Sediment Quality in Arkansas Bait Minnow Ponds. J. of the world aquaculture society. 33 (3): 221-232.

22. Thomas, G. W. 1996. Soil pH and soil acidity. In: Bartels, J.M. (Ed.), Methods of Soil Analysis, Part 3, Chemical Methods. Soil Science Society of America Book series No. 5: 475-490.

23. Thunjai T., C. E. Boyd and M. Boonyaratpalin. 2004. Bottom soil quality in tilapia ponds of different age in Thailand. Aqua. Res., 35:698-705.

24. Wudtisin, I. and C. E. Boyd. 2006. Physical and chemical characteristics of sediments in catfish, freshwater prawn and carp ponds in Thailand. Aqua. Res., 37: 1202-1214. 
الخصائص الكيميائية لراسب قاع أحواض المزارع السمكية بلالة محتواها

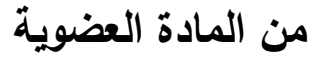

\section{سمير محمد سعيد موسى، مصطقى عبد المحسن الجمال}

مركز البحوث الزراعبة- الهعدل المركزى لبحوث الثروة السدكية بالعباسة - قسم اللينولوجى

أجريت هذه الدراسة على راسب قاع أحواض عدد من المزارع السمكية والتى تقع فى مناطق

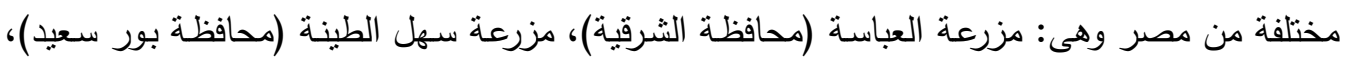

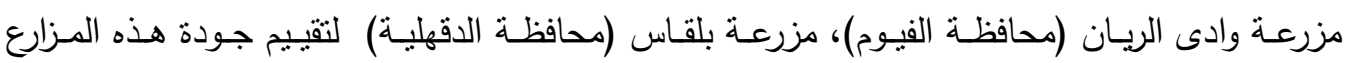

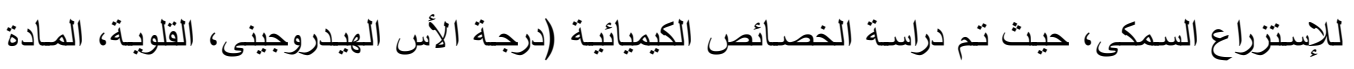
العضوية، الكربون العضوى وغير العضوى، النتروجين الكلى، الفوسفور الكلى، الفوسفور غير العضوى، لإنها،

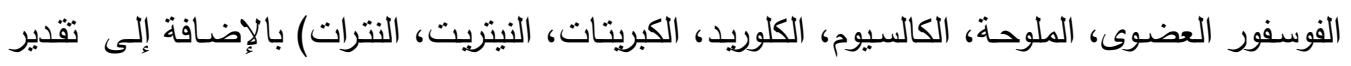

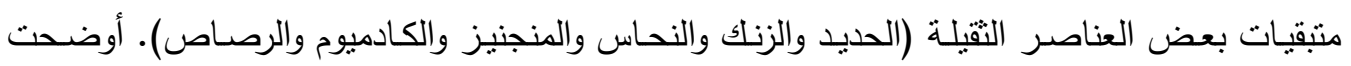
الدراسة أن راسب قاع الأحواض تخنلف فى التركيب الكيميائى والعناصر من منطقة لأخرى وقد كان

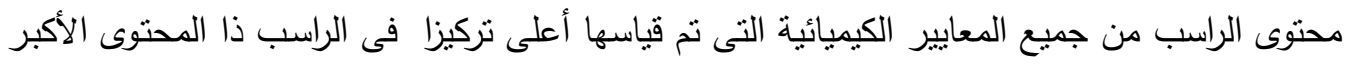
من المادة العضوية (مزرعتي العباسة و سهل الطينة)، بينما سجل الراسب ذا المحتوى الأقل من المادة العضوية (مزرعة وادى الريان و بلقاس) القيم الأقل من هذه المعايير ـ كما كانت معاملات الارتباط بين

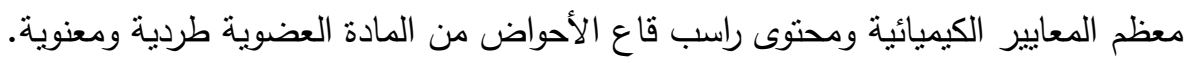

